\title{
An Examination of Gender Diversity and Editorial Boards in Finance
}

\author{
Patricia Hatfield \\ Bradley University \\ Timothy A. Kruse \\ Xavier University
}

\begin{abstract}
Women comprise only $13.7 \%$ of individuals holding the rank of full professor in finance. Since publication is a necessary condition for promotion to full professor, we examine possible reasons women publish less than men. Editorial board members determine which manuscripts are published and are the primary gatekeepers setting the course of the future direction of finance research. Thus, diversity in board membership would enhance varying research perspectives, benefitting all in the field. We examine the gender of individuals serving as editors of "pure" finance journals and find women are disproportionately underrepresented across both journal types and editorial positions.
\end{abstract}

Keywords: Academic Finance, Finance Journals, Editorial Board, Gender Diversity, Publishing, Promotion

\section{INTRODUCTION}

Universities and colleges require academics to teach, research, and serve the institution. The balance between these activities differs among universities. Accredited institutions require the publication of manuscripts to receive tenure and promotion from assistant to associate professor. Those who continue to excel in research may advance to promotion to full professor. Ideally, this process is available to all professors employed at academic institutions. However, it is not as common among women with a terminal degree in finance. While the 194 women holding the rank in finance during the 2018-2019 academic year represents an all-time high, women still comprise only $13.7 \%$ of full professors in the field. ${ }^{1}$

This paper seeks to provide insight as to why female finance professors are not achieving the rank of full professor at the same rate as their male colleagues. Numerous studies have shown that the quality and quantity of publications are the most important indicators for promotion to full professor, and that these requirements are increasing (Campbell and Morgan, 1987; Englebrecht, Iyer and Patterson, 1994; Glover, Prawitt and Wood, 2006). Thus it appears that women are not publishing as much as men. A study by Chan, Chang and Chang (2013) created a list of the top 50 most prolific researchers in finance as measured by citation counts for the top 23 finance journals. Of the 50 most-published authors, only one was female. We seek to provide insight as to why women in finance do not appear to publish as much as their male counterparts. As editorial boards serve as the gatekeepers of what is published, one particular area of interest is the proportion of women serving on the boards of those journals. 


\section{LITERATURE REVIEW}

There is no shortage of studies reporting significant gender differences in the quantity of research publications in many areas of academe. Jacquet, Bergstrom, Correll and West (2013) used the huge JSTOR database of academic articles published between 1665 and 1989. The authors analyzed two million articles written by 2.7 million scholars to determine whether there were any gender differences in the publication rates of academics. Their findings were consistent with many earlier, and smaller, studies: that women publish proportionately low shares of overall research. The authors divided the database into two roughly equal parts: articles published between 1665 and 1989, and between 1990 and 2010. They found that although the gender disparity still existed near the end of the 345 years covered, it had improved during the more recent period. Interestingly, they examined co-authorship and found that women were less likely to be the first author and were more likely to appear third, fourth or fifth. While the disparity in the gender gap regarding publications improved in the latter period, the disparity among articles with women as first authors and last authors actually grew wider. Assuming authors are listed in the order of their contribution to the manuscript, there appears to be a problem across many disciplines with regard to female representation in publications.

In an earlier study, Zuckerman (1987) reported women publish at a rate a little over half men's, and that among men and women with equivalent research records, men consistently hold higher ranks. Subsequent studies consistently found female professors published fewer manuscripts than male professors (Rebne and Davidson, 1992; Long, 1990). Furthermore, other studies contributed more detail, noting that women receive fewer citations. This makes sense if women are publishing less than their male counterparts (Cole and Zuckerman, 1984; Over, 1982; Cole, 1979). Moreover, the lack of citation hurts women's career progression (Maliniak, Powers and Walter, 2013).

Literature examining gender issues across business disciplines is consistent with the broader evidence. Lanier, Tanner and Guidry (2009) examine participation rates in accounting, economics, management and marketing. They report women's participation rates in these disciplines had reached $42 \%$ by 2002. However, they also report that at Association to Advance Collegiate Schools of Business (AACSB)-accredited schools women comprised only $24.3 \%$ of business school faculty in 2004 , with the majority of female business faculty ranked as instructor.

Additional research examines whether there is a gender gap among faculty in economics. This research indicates female faculty members publish less than their male counterparts (Barbezat, 2006; Maske, Durden and Gaynor, 2003; Broder 1993; Fish and Gibbons, 1989). However, McDowell, Singell, and Stater's (2006) study, focusing on the importance of networks when finding co-authors and publishing, contradicts the results of these earlier studies. Their results contend there was a wide gap between women and men's rates of publication in economics forty years ago. However, they report the probability of female economists publishing significantly less than their male counterparts disappeared by 1993, citing the increase in the number of women have earning their Ph.D. in economics and moving into academia. They also found that female economists were as likely to co-author as male economists, and that by working their way into this important network, women have been able to bridge the gender gap in economics.

Substantial research also exists concerning gender differences in accounting. Saftner (1988) found that the amount of time it takes to go from terminal degree to full professor is longer for women than for their male counterparts. Dwyer (1994) found that female accounting professors had fewer publications than male accounting professors. However, Dwyer found that the genders have an equal research impact, measured by the number of citations received. So, if research is measured by quantity, the gap persists, but if it is measured by impact, the gender gap in accounting publications disappears. Unfortunately, findings in accounting also show it takes female accounting professors longer to be promoted to full professor than their male counterparts.

There are several previous papers examining gender differences among finance professors regarding publication and promotion. Dyl and Hasselback (1998) report $12 \%$ of tenure track finance faculty are women. Keys and Turner (2006) investigated which female publishers are most prolific and what 
contributes to their output. They found that publication output for female authors was more of a function of available resources than the quality of the Ph.D.-granting university. The study that comes the closest to examining gender differences among finance professors was done by Keys, Owens and Turner (2009). They concluded that there is no relationship between gender and quality of publications; however, they found that male finance professors published significantly more manuscripts than their female counterparts. They also found that men publish more often with their dissertation advisors. This mentoring process is valuable for male professors, and would likely improve the outcomes for female professors as well.

Hardin, Liano, Chan, and Fok (2008) assessed the research productivity of editorial board members of five top finance journals to determine which research characteristics influence the editorial board selection process. They found that publishing in the Journal of Finance was the leading benchmark in determining editorial board membership. To become an editor for the Journal of Finance requires that board members publish in at least one of the top three finance journals, Journal of Finance, Journal of Financial Economics or Review of Financial Studies. They concluded that Journal of Finance serves as the gatekeeper for selection to editorial boards to top-tier journals. Their results also show that those that serve on the editorial boards of these journals generally publish in those same journals while they are editors. Hatfield and Webb (2015) conducted an exploratory study, using a small sample of 17 finance journals to examine if women were proportionately represented among the different ranks of professorship and on finance editorial boards. They found a significant gender gap that widened at the rank of full professor. Since promotion to full professor is highly dependent on the quality and quantity of publications, they proposed that women may not attain as many publications due to supply-side or demand-side reasons, or a hybrid of the two. Supply-side reasons include the idea that women may choose to concentrate more on teaching and less on research or make other career choices in which they do not pursue editorial board membership. Demand-side reasons would include discrimination, where some editors may view women differently, or where women do not receive the mentoring that is available to their male counterparts.

Since little work has been done to directly assess whether female finance professors are proportionately represented on finance editorial boards, we expanded upon Hatfield and Webb's (2015) work by drawing from a larger sample of "pure" finance journals, defined as journals that only publish articles in the field of finance. In other words, these journals do not accept manuscripts from other business disciplines. We also increased the time frame used by Hatfield and Webb to get a clearer picture of how serious the gender gap may be on editorial boards of finance journals and to examine how quickly or slowly these proportions are changing.

\section{Diversity and Editorial Board Membership}

Editorial boards directly influence the directions in which research in finance will progress. This influence filters down to what is taught in the classroom. An extensive body of literature addresses how diversity can impact perspective and the spectrum of issues examined (Metz, Harzing, and Zyphur, 2016; Konrad, 2008; Tung, 2006). Everybody in the discipline benefits from exposure to a variety of perspectives and issues rather than a more homogeneous point of view.

Aside from the moral responsibility academe has in providing the same opportunities for all faculty, as well as to reward faculty on a fair and equitable basis, there are many benefits in encouraging women to advance their career as readily as men do. When women's progress is hampered, students and junior faculty are not provided with sufficient female role models. AACSB data show that graduate and undergraduate enrollments in business schools have experienced a large increase in the female student populations seeking degrees (AACSB Business School Questionnaire, 2016). Fisher, Motowidlo and Werner (1993) discuss the importance of female students being educated by female professors. As role models, female professors help female students learn to navigate areas that are often male-dominated. Having more women on editorial boards will show that they are as competent and valued as their male counterparts and will help lead them along the path to promotion. It may also signal change and attract manuscript submissions from more diverse groups and perspectives (Feldman, 2008). Increasing 
awareness of this deficit in perspectives itself is important, as it may inspire a movement to include more women on finance editorial boards (Meyerson and Fletcher, 2000).

Metz, Harzing and Zyphur (2016) find that women continue to be underrepresented in the management discipline, even though there is no shortage of women willing to serve on editorial boards. The authors use social identity theory (Tajfel and Turner, 1986) and homosocial reproduction theory (Kanter, 1977; Nielson, 2009) to explain why women may not be chosen by top editors to serve on editorial boards. Social identity theory posits that individuals are more likely to support those most similar to them, e.g. men are more likely to advocate for other men rather than women. Homosocial reproduction theory posits that people prefer to work with those that are most like them. Metz, Harzing and Zyphur suggest combining these two theories to help explain the lack of women on editorial boards.

\section{Women in the Profession}

The AACSB provides information regarding faculty at accredited institutions. We examined their Staff Composition and Demographic Surveys to collect data regarding the number and percentage of women holding the rank of full, associate, or assistant professor, as well as non-tenure track instructor, at three-year intervals beginning with 2001 and ending with 2016. We report the results in Table 1.

\section{TABLE 1}

DISTRIBUTION BY RANK OF WOMEN IN THE PROFESSIONN OVER TIME

\begin{tabular}{cccccccccccccc}
\hline \multicolumn{4}{c}{ Year } & \multicolumn{3}{c}{ Full Professor } & \multicolumn{3}{c}{ Associate Professor } & \multicolumn{3}{c}{ Assistant Professor } & \multicolumn{3}{c}{ Instructor } \\
& $\mathrm{N}$ & Women & $\%$ & $\mathrm{~N}$ & Women & $\%$ & $\mathrm{~N}$ & Women & $\%$ & $\mathrm{~N}$ & Women & $\%$ \\
\hline 2001 & 980 & 57 & 5.8 & 833 & 126 & 15.1 & 767 & 154 & 20.1 & 186 & 51 & 27.4 \\
2004 & 1126 & 80 & 7.1 & 894 & 145 & 16.2 & 898 & 200 & 22.3 & 267 & 68 & 25.5 \\
2007 & 1147 & 94 & 8.2 & 926 & 158 & 17.1 & 923 & 277 & 30.0 & 342 & 91 & 26.6 \\
2010 & 1268 & 117 & 9.2 & 984 & 196 & 19.9 & 1035 & 324 & 31.3 & 422 & 101 & 23.9 \\
2013 & 1476 & 151 & 10.2 & 1190 & 283 & 23.8 & 1212 & 353 & 29.1 & 592 & 141 & 23.8 \\
2016 & 1432 & 173 & 12.1 & 1118 & 300 & 26.8 & 1162 & 310 & 26.7 & 622 & 153 & 24.6 \\
\hline
\end{tabular}

Source: Association to Advance Collegiate Schools of Business Staff Composition and Demographics Surveys

Overall, the population of both male and female professors (N) steadily grew from 2001 to 2013 in each of the four ranks. The number and percentage of women also show continuous growth from 2001 to 2016 at the full and associate ranks, increasing from 57 (5.8\% of the individuals at that rank) to 173 $(12.1 \%)$ and $126(15.1 \%)$ to $300(26.8 \%)$, respectively. There is some evidence of the trend towards a greater proportion of women at these ranks accelerated near the end of the sample period. While the overall number of people holding the rank of full and associate professor decreased in 2016, the number and proportion of women continued to increase slightly. It is disconcerting, however, to see the very low percentages of women achieving full professor rank. Taking the complement for 2016, men comprised $1259(87.9 \%)$ and $818(73.2 \%)$ of full and associate professors, respectively. So, the proportion of male full finance professors increased considerably, while dropping by more than half for women. Thus, the data in Table 1 suggest that many women are not publishing enough work perceived to be of sufficient quality to receive promotion to full professor. 
The pattern at the rank of assistant professor differs. While the number of women holding this rank doubled from 2001 to 2016 from 154 to 353, the percentage peaked in 2010, at 31.3\%, before falling back to $26.7 \%$ by 2016 . While the number of women holding the rank of instructor grew, the percentage stayed more or less constant in the mid-twenty percent range.

While we did not examine the issue, it is possible the 2008 financial crisis played a role in the 2016 fall in the number and proportion of female assistant professors. Those already holding the rank of assistant in 2013 likely started their Ph.D. studies before the crisis. However, many in the 2016 group (of both genders) will have started after the crisis. This fall in the proportion of women is consistent with the idea that women were disenchanted with the profession by the crisis in greater numbers than men.

\section{Analysis of Women on Editorial Boards}

We collected data regarding the gender composition of editorial boards at 29 "pure finance" journals (see the Appendix for the complete list). These journals were selected to cover a spectrum of potential ranking tiers. We grouped the data at three-year intervals, beginning in 1998 and ending in 2016, resulting in seven time periods for most journals. This process resulted in a total number of 196 journal-year data points. Boards typically have two or three levels of editorship; while there is no standard hierarchy of titles common to all journals, we chose the most commonly used titles in finance journals. Typically, there are from one to five managing or editors-in-chief. We refer to these editors as "managing editors." All but three journals have a second tier of between one and sixteen "advisory editors," with an average number of 3.86. Finally, all journals included in the sample have a larger group of "associate editors," ranging in number from 12 to 98 , with an average of 32.6 .

We divided the 29 journals into two groups. Drawing on the classification schemes of Borokhovich, Lee, and Simkins (2011) and Keys, Owens, and Turner (2009), we characterize a total of 11 journals as high impact: Financial Analysts Journal, Financial Management, the Journal of Finance, the Journal of Financial and Quantitative Analysis, the Journal of Financial Economics, the Journal of Financial Intermediation, the Journal of Futures Markets, the Journal of Banking and Finance, the Journal of Corporate Finance, the Journal of Money Credit and Banking, and the Review of Financial Studies.

In most cases, journals provide both the given and family name of the editors, allowing us to easily determine the gender of each board member. However, we performed internet searches for photographs of those editors whose name might belong to either gender or if only given name initials plus family name were provided (as is the case at many Elsevier journals).

We report the total number of editors along with the number and percentage of women holding each editorial position in Table 2. Overall, women are underrepresented at all three levels. The underrepresentation is particularly noticeable at the managing editor rank, where the 62 women reach a maximum of $9.7 \%$ of the total number of positions in 2007 and quickly fall thereafter. On the other hand, the number and percentage of women steadily increases at the advisory and associate editor levels, with the proportion exceeding ten percent. This increase can be seen in the growth of the number and proportion of women holding newly created editor positions. For example, the total number of advisory editorships increased by 74 positions from 1998 to 2016, while the number of women in those positions increased by 13 . So, women held $17.6 \%$ of the new positions. Among associate editors, women comprised 68 (or $22.1 \%$ ) of 307 new positions. While these numbers indicate more women have gained membership on editorial boards, overall female representation remains substantially lower than that in the profession of finance as a whole. 
TABLE 2

NUMBER AND PERCENTAGE OF WOMEN SERVING ON EDITORIAL BOARDS OVER TIME

\begin{tabular}{cccccccccc}
\hline Year & $\mathrm{N}$ & $\begin{array}{c}\text { Managing } \\
\text { Women }\end{array}$ & $\%$ & $\mathrm{~N}$ & $\begin{array}{c}\text { Advisory } \\
\text { Women }\end{array}$ & \multicolumn{3}{c}{$\begin{array}{c}\text { Associate } \\
\text { Women }\end{array}$} & $\%$ \\
\hline 1998 & 52 & 3 & 5.8 & 53 & 2 & 3.8 & 776 & 46 & 5.9 \\
2001 & 54 & 3 & 5.6 & 61 & 3 & 4.9 & 845 & 50 & 5.9 \\
2004 & 60 & 5 & 8.3 & 98 & 5 & 5.1 & 885 & 64 & 7.2 \\
2007 & 62 & 6 & 9.7 & 107 & 8 & 7.5 & 938 & 76 & 8.1 \\
2010 & 49 & 3 & 6.1 & 109 & 6 & 5.5 & 921 & 76 & 8.3 \\
2013 & 52 & 3 & 5.8 & 122 & 11 & 9.0 & 948 & 83 & 8.8 \\
2016 & 56 & 3 & 5.4 & 127 & 15 & 11.8 & 1083 & 114 & 10.5 \\
\hline
\end{tabular}

The data come from the list of editorial board members appearing in the first issue of a given calendar year. The list of 29 journals examined appears in the appendix.

We report the number and percentage of women holding the three types of editorial positions by journal impact level in Table 3. High-impact journals have significantly higher average proportions of women in the managing and associate editor positions at the $1 \%$ level. In contrast, the proportion of women holding advisory editor positions is marginally lower (significant at the $10 \%$ level). ${ }^{2}$ High-impact journals experience more change in managing editors; they experience higher turnover or have newly created positions at the editorial level in $48 \%$ of journal-years, versus only $21 \%$ among the remaining journals. This higher turnover rate provides more opportunities for women to be appointed, which in turn allows for more new perspectives at these journals. However, the lower turnover among managing editors at other journals might harm women's prospects at less research-intensive institutions. Even so, men continue to dominate the position over time (Table 4).

TABLE 3

WOMEN IN EDITORIAL POSITIONS BY JOURNAL RANK BASED IN TYPE OF JOURNAL

\begin{tabular}{|c|c|c|c|c|c|}
\hline & \multicolumn{2}{|c|}{ High-Impact Journals } & \multicolumn{2}{|c|}{ Other Journals } & \multirow{2}{*}{$\begin{array}{c}\text { t-stat } \\
\% \text { women } \\
\text { equal }\end{array}$} \\
\hline & Women & $\%$ & Women & $\%$ & \\
\hline Managing editor & 22 & 10.9 & 4 & 1.6 & $3.48 * * *$ \\
\hline Advisory editor & 21 & 6.6 & 29 & 11.7 & $1.78^{*}$ \\
\hline Associate editor & 254 & 9.8 & 255 & 6.6 & $23.53 * * *$ \\
\hline Number of journals & \multicolumn{2}{|c|}{11} & \multicolumn{2}{|c|}{18} & \\
\hline
\end{tabular}

Total number of women and average percentages based on journal-year. The list of journals appears in the appendix. The $\mathrm{t}$-stat is for differences in average percentage. $* * *, * *$, and $*$ indicate the average percentage of women holding editorial positions is significantly different at the $1 \%, 5 \%$, and $10 \%$ levels, respectively. 
TABLE 4

WOMEN IN EDITORIAL POSITIONS BY TIME AND JOURNAL RANK

\begin{tabular}{|c|c|c|c|c|c|c|c|c|c|c|c|c|}
\hline \multirow{3}{*}{ Year } & \multicolumn{6}{|c|}{ High-Impact Journals } & \multicolumn{6}{|c|}{ Other Journals } \\
\hline & \multicolumn{2}{|c|}{ Managing } & \multicolumn{2}{|c|}{ Advisory } & \multicolumn{2}{|c|}{$\underline{\text { Associate }}$} & \multicolumn{2}{|c|}{ Managing } & \multicolumn{2}{|c|}{$\underline{\text { Advisory }}$} & \multicolumn{2}{|c|}{ Associate } \\
\hline & \# & $\begin{array}{c}\text { Avg } \\
\%\end{array}$ & \# & Avg $\%$ & \# & $\begin{array}{c}\text { Avg } \\
\%\end{array}$ & $\#$ & Avg \% & \# & $\begin{array}{c}\text { Avg } \\
\%\end{array}$ & $\#$ & Avg \% \\
\hline 1998 & 3 & 11.5 & 0 & 0.0 & 20 & 6.1 & 0 & 0.0 & 2 & 6.9 & 26 & 5.8 \\
\hline 2001 & 3 & 11.5 & 1 & 3.8 & 21 & 6.8 & 0 & 0.0 & 2 & 5.7 & 29 & 5.4 \\
\hline 2004 & 4 & 13.3 & 3 & 6.1 & 30 & 8.6 & 1 & 3.3 & 2 & 4.1 & 34 & 6.3 \\
\hline 2007 & 5 & 19.2 & 3 & 5.6 & 39 & 10.5 & 1 & 2.8 & 5 & 9.4 & 37 & 6.5 \\
\hline 2010 & 2 & 10.0 & 2 & 3.8 & 36 & 10.7 & 1 & 3.4 & 4 & 7.1 & 40 & 6.9 \\
\hline 2013 & 2 & 9.5 & 5 & 9.3 & 50 & 13.9 & 1 & 3.2 & 6 & 8.8 & 33 & 5.6 \\
\hline 2016 & 3 & 13.0 & 7 & 12.7 & 58 & 13.8 & 0 & 0.0 & 8 & 11.1 & 56 & 8.4 \\
\hline
\end{tabular}

The list of journals appears in the appendix.

The changes at the managing editor level at high-impact journals are reflected in the results presented in Table 4, which shows the number and proportion of women holding various positions over time. The aggregate number and proportion of women among managing editors at high-impact journals is never high, ranging from 2 to 5 women and 9.5 to $19.2 \%$, respectively. Even so, these figures are higher than those for the other 18 journals, among which there is only one female managing editor in four of the seven time periods, and zero in the other three time periods. There is a slight increase over time for advisory and associate editors at both classes of journal, though the trend is most pronounced among the higher-impact journals. There is one small piece of hope for women in the future: the total number of associate editors among the high-impact journals increased from 328 to 420 over our sample period, an increase of 92 . The number of women in this role increased by 38 , representing $42 \%$ of the new positions. With time, some of these women may be promoted to managing editors.

\section{DISCUSSION}

The literature examines several theories regarding why women take longer to progress from assistant professor to associate professor, and why a disproportionately large number of women never attain full professorship. Research productivity is a key issue in progressing through the ranks, with a strong emphasis on research required to attain the rank of full professor. McDowell and Smith (1992) report that academics tend to co-author with individuals of the same gender. They argue the prevailing gender imbalance made it more difficult for women to find same-gender colleagues as co-authors. This problem likely persists to this day within the finance discipline. Ferber and Teiman's (1980) study supports this, finding women have more trouble than men both in finding co-authors and having research papers accepted for publication.

Zuckerman (1987) proposed four possible explanations for the existence of this gender gap with regard to publications: (1) ability difference, (2) self-selection, (3) social-selection, and (4) accumulative advantage/disadvantage. Zuckerman addresses each of these in turn, citing studies that dispute a difference in abilities. He describes the result for self-selection as mixed: self-selection implies women may prefer to spend more time teaching than researching, or may choose to dedicate more time to family and children. However, Bellas and Toutkoushian (1999) found that marriage was positively related to research output for both men and women. Barbezat (2006) reported that female economics professors at universities spent more time on their classes than their male counterparts, and slightly less time doing research. But another important gender difference is that female academics conducted most of their research in the summer while men reported that they did most of their research throughout the academic year. This preference could indicate women may choose to devote themselves to children and family 
during the academic year and attempt to make up for the difference in the summer. Social-selection implies discrimination based on gender as well as an environment and infrastructure that allocates resources such that women are viewed as subjacent to their male counterparts. Hornig (1987) notes a time when it was an institutional policy to not allow women into graduate school, though that is no longer true. Fortunately, the exclusion of women from attending graduate school or working as a professor is now illegal. With regard to the fourth explanation, accumulative advantage/disadvantage, there are numerous studies that suggest different ways female academics accumulate large disadvantages over time compared to their male counterparts (Long, 1990, Clark and Corcoran, 1986; Cole 1979; Cole and Cole, 1973). Examples discussed in these studies include superior opportunities and rewards offered to men compared to women; the general way women may be treated; women perhaps having less access to high-quality graduate programs; and differences in mentoring offered to the genders.

We suggest that the disproportionately low representation of female finance professors on finance editorial boards serves as one of these cumulative disadvantages. Proportional membership on an editorial board is important for several reasons. First, it comes with a level of stature and accomplishment that provides more exposure and networking possibilities. Second, it serves as a signal of the individual's scholarly recognition. Both of these benefits are valued by the academic community and help propel professors through the ranks. Since women are not proportionately represented as members of editorial boards, this disparity may help explain why the gender gap continues to be significant in finance, particularly at the rank of full professor. Other factors certainly contribute to the lack of promotion for women in the field, but the loss of networking opportunities, lack of mentoring, and lack of reward for female professors' academic accomplishments appears to be very real.

\section{CONCLUSION}

As in so many other disciplines, the gender gap in promotion and in membership of editorial boards is a real phenomenon in finance. To mitigate this issue would require that the editors at top-tier journals make a purposeful effort to include more women on their editorial boards. In doing this, they will help expose more women to networking connections, which may lead to more co-authorship opportunities. This, in turn, may encourage more women to submit manuscripts to those journals, providing the discipline with potentially fresh perspectives. At the same time, these journals are signaling to women that their contributions to the field matter and are valued. It is hoped that these changes would contribute to eventually closing the gender gap that exists within academic ranks, particularly at the full professor level.

\section{ENDNOTES}

1. AACSB 2018-19 Staff Compensation and Demographics Survey

2. The results comparing sub-sample medians or by re-categorizing our high-impact journals using the higher quality journals listed in Borokhovich, Lee, and Simkins (2011) and Keys, Owens, and Turner (2009) individually are substantially the same. 


\section{REFERENCES}

Association to Advance Collegiate Schools of Business. Staff Composition and Demographics Surveys. (1998-2016).

Association to Advance Collegiate Schools of Business. Business School Questionnaire. (1998-2016)

Barbezat, D. (2006). Gender Differences in Research Patterns Among PhD Economists. The Journal of Economic Education, 37(3), 359-375.

Borokhovich, K., Lee, A., \& Simkins, B. (2011). A Framework for Journal Assessment: The Case of the Journal of Banking \& Finance. Journal of Banking \& Finance, 35(1), 1-6.

Bellas, M., \& Toutkoushian, R. (1999). Faculty Time Allocations and Research Productivity: Gender, Race and Family Effects. Review of Higher Education, 22(4), 367-390.

Broder, I. E. (1993). Professional Achievements and Gender Differences Among Academic Economists. Economic Inquiry, 31(1), 116-127.

Campbell, D. R., \& Morgan, R. G. (1987). Publication Activity of Promoted Accounting Faculty. Issues in Accounting Education, 2 (1) Spring, 28-43.

Chan, K., Chang, C., \& Chang, Y. (2013). Ranking of finance journals: Some Google Scholar Citation Perspectives. Journal of Empirical Finance, 21, 241-250

Clark, S., \& Corcoran, M. (1986). Perspectives on the Professional Socialization of Women Faculty: A Case of Accumulative Disadvantage? The Journal of Higher Education, 57(1), 20.

Cole, J. R. (1979). Fair Science: Women in the Scientific Community. New York: The Free Press. Macmillan Publishing.

Cole, J.R., \& Cole, S. (1973). Social Stratification in Science. Chicago and London. The University of Chicago Press.

Cole, J.R., \& Zuckerman, H. (1984). Gender Differences in Research Productivity. Retrieved from https://www.the-scientist.com/commentary/gender-differences-in-research-productivity-56342.

Dwyer, P. D. (1994). Gender Differences in the Scholarly Activities of Accounting Academics: An Empirical Investigation. Issues in Accounting Education, 9, Fall, 231-242.

Dyl, E. A., \& Hasselback, J. R. (1998). The Hiring of Women in Finance Academia. Journal of Financial Education, 24, 1-7.

Englebrecht, T. D., Iyer, G. S., \& Patterson D. M. (1994). An Empirical Investigation of the Publication Productivity of Promoted Accounting Faculty. Accounting Horizons, 8(1) March, 45-68.

Feldman, D. C. (2008). Building and Maintaining a Strong Editorial Board and Core of Ad Hoc Reviewers. In Baruch, Y. Opening the Black Box of Editorship. New York, NY: Palgrave Macmillan, 68-74.

Ferber, M., \& Teiman, M. (1980). Are Women at a Disadvantage in Publishing Journal Articles? Eastern Economic Journal, 6(3-4), 189-193.

Fish, M., \& Gibbons, J. D. (1989). A Comparison of the Publications of Female and Male Economists. Journal of Economic Education, 20, Winter, 93-105.

Fisher, B., Motowidlo, S., \& Werner, S. (1993). Effects of Gender and Other Factors on Rank of Law Professors in Colleges of Business: Evidence of a Glass Ceiling. Journal of Business Ethics, 12(10), 771-778.

Glover, S., Prawitt, D., Summers, S., \& Wood, D. (2012). Publication Benchmarking Data Based on Faculty Promoted at the Top 75 U.S. Accounting Research Institutions. Issues in Accounting Education, 27(3), 647-670.

Hardin, W., Liano, K., Chan, K., \& Fok, R. (2008). Finance Editorial Board Membership and Research Productivity. Review of Quantitative Finance and Accounting, 31(3), 225-240.

Hatfield, P., \& Webb, S. (2015). The Role of Gender in Academic Finance Journals: An Exploratory Study. American Journal of Business Education, 8(4), 249-258.

Hornig, L. (2019). Retrieved from https://www.nap.edu/read/18771/chapter/8.

West, J.D., Jacquet J., King M. M., Correll, S. J., \& Bergstrom, C.T. (2013) The Role of Gender in Scholarly Authorship. PLoS ONE, 8(7), e66212. https://doi.org/10.1371/journal.pone.0066212

140 Journal of Accounting and Finance Vol. 19(8) 2019 
Kanter, R. M. (1977). Men and Women of the Corporation. New York, N.Y.: Basic Books.

Keys, P.Y., \& Turner, P.A. (2006). Women as Finance Academics: Role Models and Researchers. Journal of Financial Education, Summer, 1-19.

Keys, P. Y., Owens, W. L., \& Turner, P. A. (2009). A Gender Analysis of Productivity and Quality in Finance Research. Journal of Financial Education, Spring, 66-79.

Konrad, A. M. (2008). Knowledge Creation and the Journal Editor's Role. In Baruch, Y. Opening the Black Box of Editorship. New York, NY: Palgrave Macmillan, 3-15.

Lanier, P., Tanner, J., \& Guidry, B. (2009). A Comparison of Gender and Gender-Related Issues in the Business Disciplines. Public Personnel Management, 38(3), 51-70.

Long, J. (1990). The Origins of Sex Differences in Science. Social Forces, 68(4), 1297-1315.

Maliniak, D., Powers, R., \& Walter, B. (2013). The Gender Citation Gap in International Relations. International Organization, 67(4), 889-992.

Maske, K., Durden, G., \& Gaynor, P. (2003). Determinants of Scholarly Productivity among Male and Female Economists. Economic Inquiry, 41(4), 555-564.

McDowell, J., Singell, L., \& Stater, M. (2006). Two to Tango? Gender Differences in the Decisions to Publish and Coauthor. Economic Inquiry, 44(1), 153-168.

McDowell, J.M., Singell, Jr. L.D., \& Ziliak, J.P. (2001). Gender and Promotion in the Economics Profession. Industrial and Labor Relations Review, 54(2), 224-244.

McDowell, J. M., \& Smith., J. (1992). The Effect of Gender Sorting on Propensity to Coauthor: Implication for Academic Promotion. Economic Inquiry, 30(1), 68-82.

Metz, I., Harzing, A., \& Zyphur, M. (2016). Of Journal Editors and Editorial Boards: Who Are the Trailblazers in Increasing Editorial Board Gender Equality? British Journal of Management, 27(4), 712-726.

Meyerson, D.E., \& Fletcher, J.K. (2000), A Modest Manifesto for Shattering the Glass Ceiling. Harvard Business Review, January/February, 127-36.

Nielson, S. (2009). Why Do Top Management Teams Look the Way They Do? A Multilevel Exploration of the Antecedents of TMT Heterogeneity. Strategic Organization, (7), 227-305.

Over, R. (1982). Research Productivity and Impact of Male and Female Psychologists. American Psychologist, (January), pp. 24-31.

Rebne, D., \& Davidson, N. (1992). Understanding Patterns of Publishing Activity in Academic Research Occupations. Decision Sciences, 23(4), 944-956.

Saftner, D.V. (1988). The Promotion of Academic Accountants. Journal of Accounting Education, (Spring), 55-66.

Tajfel, H., \& Turner, J. C. (1986). The Social Identity Theory of Intergroup Behaviour. In S. Worchel, S. and Austin, W. G., $2^{\text {nd }}$ Edition. 7-24. Chicago: Nelson-Hall.

Tung, R. (2006). North American Research Psychology of Intergroup Relations Agenda and Methodologies: Past Imperfect, Future — Limitless Possibilities. Asian Business \& Management, 5(1), 23-35.

Zuckerman, H. (1987). Persistence and Change in the Careers of Men and Women Scientists and Engineers. Women: Their Underrepresentation and Career Differentials in Science and Engineering. Edited by L. S. Dix, 127-156. Washington, D.C.: National Academy Press. 


\section{APPENDIX}

\section{Journals used in the study}

High-Impact Journals

Financial Analyst Journal

Financial Management

Journal of Banking and Finance

Journal of Corporate Finance

Journal of Finance

Journal of Financial and Quantitative Analysis

Journal of Financial Economics

Journal of Financial Intermediation

Journal of Futures Markets

Journal of Money Credit and Banking

Review of Financial Studies

Other Journals

Finance and Stochastics

Financial Review

Global Finance Journal

International Finance

Journal Fixed Income

Journal of Alternative Investments

Journal of Applied Corporate Finance

Journal of Derivatives

Journal of Empirical Finance

Journal of Financial Markets

Journal of Financial Research

Journal of International Financial Markets, Institutions and Money

Journal of Investing

Journal of Multinational Finance

Journal of Portfolio Management

Pacific Basin Finance Journal

Quantitative Finance

Review of Futures Markets

142 Journal of Accounting and Finance Vol. 19(8) 2019 